\title{
Opportunity makes the thief. Really? And so what?
}

\author{
Ronald V Clarke
}

\begin{abstract}
Background: This paper describes the work undertaken over many years by the author and colleagues concerning the role of opportunity in crime. The work began in the early 1970s in the Home Office Research Unit, the British government's criminological research department.

Discussions: The work supported a preventive approach - situational crime prevention - that was highly contentious in the criminology of the day because it sought to reduce opportunities for crime, rather than to modify offender propensities. Critics claimed that situational crime prevention would displace rather than reduce crime because they assumed that opportunity merely determines the time and place of crime, but does not cause it.
\end{abstract}

Summary: This paper describes the difficulties in establishing that opportunity is cause of crime and why this took so long. It reviews the research that was undertaken to this end, and it summarizes the benefits for criminology and crime policy of accepting that opportunity does cause crime.

Keywords: Crime causation, Situational crime prevention, Opportunity theory, The rational choice perspective, Routine activities theory, Environmental criminology, Administrative criminologists

\section{Introduction}

This paper describes the work on opportunity and crime since it was put on the agenda some 35 years ago in the Home Office publication, Crime as Opportunity (Mayhew et al. 1976). As described by Hough and Mayhew (2011, this work began in the early 1970s, when the two of them and I were employed in the Home Office Research Unit. In this paper, I will focus on a question that pre-occupied us then and later: Is opportunity a cause of crime? The question was unavoidable because if opportunity is a cause, then reducing it could be expected to reduce crime without displacing it; if opportunity merely determined when and where crime occurred, but did not cause it, then the expected result of reducing opportunity would simply be to displace it.

Despite its importance, no attempt was made to resolve this question in Crime as Opportunity, but twenty-two years later Felson and I felt able to claim that opportunity is a cause of crime (see Opportunity Makes the Thief, Felson and Clarke, 1998). This change needs some explanation and this paper addresses four pertinent questions ${ }^{a}$ :

Correspondence: rclarke@andromeda.rutgers.edu

University Professor, School of Criminal Justice, Rutgers, the State University of New Jersey, 123 Washington St, Newark, NJ 07102, USA
1. Why did Crime as Opportunity published in 1976 avoid making the claim that opportunity is cause of crime?

2. What had changed by the time that Opportunity makes the Thief was published in 1998?

3. What has happened since claiming that opportunity causes crime?

4. What has been achieved by the work on opportunity and crime - i.e. "So what"?

\section{Why did Crime as Opportunity (1976) not claim that} opportunity is a cause of crime?

The short answer to this question is that the reason was a mixture of conceptual confusion and timidity. Regarding the latter, to have claimed that opportunity is a cause of crime would have gone quite contrary to the criminology of the day, which was heavily dispositional (it still is). This dispositional bias can be traced back to Sutherland, a sociologist, often described as the father of criminology. In his introduction to Principles of Criminology (3rd ed. Sutherland (1947)), he expressed the opinion:

"The problem in criminology is to explain the criminality of behavior, not the behavior, as such" (page 4)....The situation operates in many ways, of which perhaps the least important is the provision of an opportunity for a criminal act" (page 5).

\section{实}

(c) 2012 Clarke; licensee Springer. This is an Open Access article distributed under the terms of the Creative Commons Attribution License (http://creativecommons.org/licenses/by/2.0), which permits unrestricted use, distribution, and reproduction in any medium, provided the original work is properly cited. 
This seems to have been broadly accepted by criminologists, most of whom like Sutherland were also sociologists, but it flouted a fundamental principle of psychology: behavior is the product of the interaction between environment and organism. In criminological terms, this can be expressed as "crime is the result of an interaction between a motivated offender and a criminal opportunity". The importance of taking this principle seriously ${ }^{b}$ had been brought home to me by the results of a study of absconding from training schools (Clarke and Martin 1971). This found that absconding was better explained by the environments and regimes of the training school, which facilitated and provoked absconding, than by absconders' personalities and backgrounds. The study therefore showed not just that situational opportunities and provocations to abscond were important explanatory factors, but they appeared to be more important than dispositional factors.

Before proceeding it should be noted that Sutherland in fact recanted his views about the role in crime played by opportunity and situation in a little-known unpublished paper, "The Swansong of Differential Association" (his theory of crime causation), which was later issued in a collection of his writings (Cohen et al. 1956). ${ }^{\mathrm{c}}$ The paper included the following passage:

"One factor in criminal behavior that is at least partially extraneous to differential association is opportunity. Criminal behavior is partially a function of opportunities to commit specific classes of crime, such as embezzlement, bank burglary or illicit heterosexual intercourse. Opportunities to commit crimes of these classes are partially a function of physical factors and of cultures which are neutral as to crime. Consequently, criminal behavior is not caused entirely by association with criminal and anticriminal patterns, and differential association is not a sufficient cause of criminal behavior." (Sutherland, 1956:31, quoted by Merton, 1995: 38).

Unfortunately, we were not aware of this retraction when we wrote Crime as Opportunity. In addition, we found it difficult to muster unambiguous evidence supporting our views about the role of opportunity in crime. d The absconding work mentioned above had gone unnoticed by criminology and, because it dealt with institutional misbehavior, would hardly be convincing as the basis for generalizing about all crime. The same could be said of Mischel's (1968) psychological studies and the Studies in Deceit published by Hartshorne and May (1928) work that we cited. The former studies established that behavior could not be reliably predicted from personality test scores because it was heavily determined by situational factors, while the latter work showed that whether children cheated on tests or behaved dishonestly depended mostly on situational variables such as the risks of being found out. In both cases, there was a considerable stretch between our thesis on opportunity and Mischel's findings (too abstract) and those of Hartshorne and May (relating to minor juvenile transgressions in artificial settings). ${ }^{\mathrm{e}}$

Finally, the two empirical studies included in Crime as Opportunity provided only mixed support for the causal role of opportunity. The first study showed that doubledeck buses suffered more vandalism on the front upper deck and other parts of the bus that could not be easily supervised by the bus crew. Strictly speaking, this showed only that lack of supervision determined the vandal's choice of where to target. The second study examined the effect on car theft of the compulsory fitting of steering column locks in England and Germany. In England, only new cars were fitted with the locks with the result, consistent with dispositional theory, that thefts were displaced to older cars without the locks. In Germany, all cars, new and old were fitted with the locks. This ruled out displacement with the result, consistent with situational theory, of an immediate and sustained decline in theft of cars. To us these results were not in conflict, but to our critics they were seen as providing support for either side of the argument about the role of opportunity in crime.

Apart from these strands of evidence, two books published in the early 1970s gave us some encouragement Jeffery (1971) Crime Prevention through Environmental Design, which argued that criminologists had neglected the biological and physical determinants of crime (including opportunity), and Oscar Newman's (1972) Defensible Space, which claimed that the high crime levels of public housing projects in the United States were due as much to the criminogenic designs of the projects as to the nature of the residents. Unfortunately, neither book proved helpful to the argument that opportunity was a neglected cause of crime because they were both given short shrift by criminological reviewers - Jeffery's because of his views about the biological causation of crime and Newman's because of its anthropomorphic conception of human "territoriality" and shortcomings in its statistical analyses (Newman was an architect, not a social researcher).

Thus, the lack of clear supporting evidence is one reason why Crime as Opportunity did not make the case that opportunity is a cause of crime, but another was the widespread belief at the time that social science could not establish causal relationships. This led us - me in particular - into a confusing exploration of the notion of cause in social science. I was impressed by Barbara Wootton's (1950) argument about the infinitely regressive nature of cause: 
The search for causal connections between associated phenomena simply resolves itself into a long process of "explaining" one association in terms of another. If a person becomes ill with what are known as diabetic symptoms, we measure the sugar-content of his blood. If this is higher than that found in people not exhibiting such symptoms, we say that the high sugar content is the cause of the illness. .. this in turn is said to be "explained" by a failure of the pancreas to function normally..... And so on with one law of association following another.." (page 18).

This argument, made by a greatly respected social scientist, ${ }^{\mathrm{f}}$ led me to think that it would be impossible to claim that opportunity was a cause of crime without becoming entangled in endless philosophical arguments, and I turned instead to the notion of necessary and sufficient conditions. Once again, I spent sleepless hours trying to decide whether opportunity was a necessary or a sufficient cause of crime, becoming confused about the meanings of each, and then deciding that sorting one from the other would still not allow us to claim that opportunity was a cause of crime.

A further deterrent was that to claim that opportunity caused crime would require us to define opportunity. Here again the difficulties seemed overwhelming. Any definition would have to take account of the fact that opportunities are highly crime specific - those that "cause" bank robbery are quite different from those that cause rape. In addition, for any crime, opportunities occur at several levels of aggregation. To take residential burglary as an example, a macro level, societal-level cause might be that many homes are left unguarded in the day because most people now work away from home (cf. Cohen and Felson 1979). A meso-level, neighborhood cause could be that many homes in poor public housing estates once used coin-fed fuel meters which offered tempting targets for burglars (as found in Kirkholt, Pease 1991). A micro-level level cause, determining the choices made by a burglar, could be a poorly secured door. Finally, at any particular level of explanation, for any specific crime, the opportunities are vast. For example micro-level opportunities include not just an unlocked door, but an open window, an isolated location, bushes that provide cover, signs of wealth, etc.

A final reason for avoiding the controversial claim that opportunity was a cause of crime was that we were not university scientists, with the authority implied by that status, but government researchers. Worse we were what came to be called administrative criminologists, uncritically serving our civil service masters, though as it proved, many of these masters were as skeptical about situational prevention as most academics of the time proved to be.

\section{What had changed by the time that Opportunity makes the Thief was published in 1998?}

Twenty-two years after the publication of Crime as Opportunity, Felson and I finally asserted in Opportunity Makes the Thief (Felson and Clarke, 1998) that opportunity is a cause of crime. What took so long? The explanation begins with the reception given to Crime as Opportunity, which was generally dismissed (more in conversation than in print) as irrelevant, simplistic and atheoretical. The first review, which concludes with the following sentences, gives a flavor of this reaction:

"Now that the criminological kitchen is becoming so hot, it is as if the (Home Office) Research Unit is looking for a nice, quiet, simple, and nonpolitical corner. It is a touching, if unworldly idea - like playing with one's toes. But it won't catch on."

(Beeson, 1976: 20).

The publication was also criticized for denying the influence of the "root causes" of crime - maternal deprivation, subculture, relative deprivation and anomie that criminologists had so patiently documented over the years. The fact that our critics felt little inhibition in claiming that their theories were causal in nature meant that our caution had been wasted. This strengthened our resolve to be more assertive about the causal role of opportunity, but this only became possible much later as a consequence of the following developments:

1. Quite soon after the publication of Crime as Opportunity, we found we were not alone in our views: Cohen and Felson (1979) and the Brantingham and Brantingham (1981) working respectively in the United States and Canada, had persuasively argued that explaining crime involved not merely explaining criminal dispositions but also explaining the role of immediate circumstance and situations.

2. In order to underpin situational prevention, Cornish and I developed the rational choice perspective (Clarke and Cornish 1985; Cornish and Clarke 1986). While this was also heavily criticized (cf. Clarke (In Press)), it should have been clear that the theory underlying Crime as Opportunity was far from simple-minded.

3. Some helpful theoretical work on causation began to appear in the years after the publication of Crime as Opportunity. Felson cut through our prevarications about free-will and determinism in the original formulation of the rational choice perspective (Clarke and Cornish 1985) by declaring that: "People make choices, but they cannot choose the choices available to them" (Felson 1986: 119). Ekblom (1994) made a 
useful distinction between near and far causes of crime, with the rider that, as a near cause, opportunity had a more powerful and immediate effect on crime than criminal dispositions formed many years before. Distinguishing between near and far causes provided a solution to Barbara Wootton's problem of infinitely regressive causes. Tilley reinforced Ekblom's position by insisting that the mechanisms through which a cause was supposed to exert its effect should always be clearly specified (cf. Tilley and Laycock 2002). This again favored opportunities over dispositions because the causal mechanisms of situation and opportunities were so much shorter and easier to chart. Following a different line of argument, but one that endorsed the practical value of focusing on reducing crime opportunities, James Q Wilson (1975) stated that if criminologists persisted in framing theories in terms of "causes" that could not be changed (e.g. maternal deprivation or relative deprivation), they would be consigned to policy irrelevance.

4. A number of studies were published during this period providing strong evidence about the causal role of opportunity, several of which I undertook with Pat Mayhew. First, we showed in Mayhew et al. (1989) that the introduction of helmet laws in various countries had a dramatic effect in reducing theft of motorcycles, apparently because motorcycle thefts were frequently unplanned which meant that opportunistic thieves would be immediately noticed when riding past without a helmet. Table 1 shows data from Germany where the laws were progressively enforced, having been first brought into effect in 1980. The table shows that motor cycle thefts were greatly reduced with little if any consistent evidence of displacement to car or bicycle thefts.

Second, we showed (Clarke and Mayhew 1988), that the $35 \%$ decline in numbers of suicides occurring in England and Wales between 1958 and 1977 was caused by a progressive reduction in the poisonous

Table 1 Thefts of motorcycles, cars and bicycles in Germany

\begin{tabular}{lccc}
\hline Year & Motorcycles & Cars & Bicycles \\
\hline 1980 & 153,153 & 64,131 & 358,865 \\
1981 & 143,317 & 71,916 & 410,223 \\
1982 & 134,735 & 78,543 & 453,850 \\
1983 & 118,550 & 82,211 & 415,398 \\
1984 & 90,008 & 72,170 & 376,946 \\
1985 & 73,442 & 69,659 & 337,337 \\
1986 & 54,208 & 70,245 & 301,890 \\
\hline
\end{tabular}

Source: Mayhew et al. 1989.
Table 2 Suicides in England and Wales, 1958-1977

\begin{tabular}{lccc}
\hline Year & Total suicides & Suicides by domestic gas & Percent of total \\
\hline 1958 & 5,298 & 2,637 & 49.8 \\
1959 & 5,207 & 2,594 & 49.8 \\
1960 & 5,112 & 2,499 & 48.9 \\
1961 & 5,200 & 2,379 & 45.8 \\
1962 & 5,588 & 2,469 & 44.2 \\
1963 & 5,714 & 2,368 & 41.4 \\
1964 & 5,566 & 2,088 & 37.5 \\
1965 & 5,161 & 1,702 & 33.0 \\
1966 & 4,994 & 1,593 & 31.9 \\
1967 & 4,711 & 1,336 & 28.4 \\
1968 & 4,584 & 988 & 21.6 \\
1969 & 4,326 & 790 & 18.3 \\
1970 & 3,940 & 511 & 13.0 \\
1971 & 3,945 & 346 & 8.8 \\
1972 & 3,770 & 197 & 5.2 \\
1973 & 3,823 & 143 & 3.7 \\
1974 & 3,899 & 50 & 1.3 \\
1975 & 3,693 & 23 & 0.6 \\
1976 & 3,816 & 14 & 0.4 \\
1977 & 3,944 & 8 & 0.2 \\
\hline 5046 & & & \\
\hline
\end{tabular}

Source: Clarke and Mayhew (1988).

carbon monoxide content of domestic gas.

(See Table 2). These reductions resulted from costsaving measures and were brought about, first, by a change in manufacture from coal-based to oil-based gas and then the substitution of natural gas from the North Sea which contained no carbon monoxide. Suicides by domestic gas which accounted for $50 \%$ of the deaths at the beginning of the period were virtually eliminated by the end of the period and their decline precisely tracked, year-by-year, the decline in the carbon monoxide content of domestic gas - strong evidence of a causal relationship. There was little displacement to other methods of suicide when domestic gas was detoxified, presumably because these methods were more difficult, painful or distasteful. Third, in the same publication we sought to explain why rates of homicide were eight times greater in the United States than in England and Wales during the mid-1980s, when rates for most other crimes differed little between the two countries. This difference was the result of a much higher rate of gun homicides in the United States, particularly handgun homicides, which in turn was due to much higher levels of gun ownership - a situational variable - in that country than in England and Wales. ${ }^{g}$

Fourth, using data from the British Crime Survey, we showed (Clarke and Mayhew, 1998) that risks of 
car theft in public car parks were eleven times greater than when cars were parked for the same length of time in the owner's driveway and 225 times greater than when parked in the owner's garage. These large differences in risk seemed to us to be strong evidence that the low risk of stealing cars from parking lots caused theft and did not merely facilitate it.

5. The motorcycle helmet study and the suicide study were just two of the many studies that appeared during the period showing that the risks of displacement had been exaggerated. This was confirmed in a review of these studies by Eck (1993) and by Hesseling (1994) who reported that no displacement was found in many studies and that, when found, the number of crimes displaced were many fewer than those prevented. Hesseling also reported the encouraging finding of his review that "diffusion of benefits" (Clarke and Weisburd 1994), where crime reductions are found beyond the intended reach of opportunity-reduction measures, was a common result of situational prevention. ${ }^{\mathrm{h}}$

6. Apart from the specific pieces of research mentioned above, there was remarkable growth in scholarly activity concerned with opportunity-reduction. Under Gloria Laycock's leadership, the Crime Prevention Unit in the Home Office and subsequently the Police Research Group published some 150 relevant reports. ${ }^{\mathrm{i}}$ In the United States, Crime Prevention Studies, a book series devoted to situational crime prevention, had issued 8 volumes by 1998. The first edition of Felson (1994)/Crime and Everyday Life, which has sold many thousands of copies, and which has done more than any other publication to disseminate findings about the role of opportunity in crime, was published in the United States. Finally, the establishment in 1992 of the annual meetings of the Environmental Crime and Crime Analysis (ECCA) group has served to build a world-wide network of scholars interested in the situational determinants of crime.

The developments listed above had transformed the evidential base for asserting the powerful role of opportunity in crime. Consequently, Felson and I readily agreed to Gloria Laycock's request made in 1998 to write a paper arguing that opportunity was a cause of crime. If published in the Police Research Series as intended, she believed the paper would materially help in persuading police and local authorities to make more use of situational prevention. Without resolving the philosophical issues around the concept of cause, we simply decided to assert in Opportunity Makes the Thief that opportunity is an important cause of crime

\section{After Opportunity Makes the Thief}

Much has happened after publication of Opportunity Makes the Thief to reinforce these claims about the role of opportunity in crime.

Valuable studies have continued to accumulate on displacement and diffusion of benefits, including one showing that the installation of 3178 lockable gates to restrict access to alleys behind row houses in Liverpool saved $£ 1.86$ in costs of residential burglary for every $£$ spent on the gates during the first year after installation. There was little apparent displacement but clear evidence of a diffusion of benefits to nearby streets without the gates (Bowers et al. 2004) and these benefits were sustained in later years (Armitage and Smithson 2007). Another strong study, undertaken in the United States, showed that system modifications made by cell phone companies eliminated a problem of cell phone cloning that at its height in 1996 had cost as much as $\$ 800$ million in one year. There was no evidence of displacement to the second most common form of cell phone fraud, acquiring cell phone service through the presentation of false ID (Clarke et al. 2001). These studies were included in an important review published in Criminology, the discipline's leading journal, of 102 situational prevention studies. This review found that: (1) no displacement was found in 68 of the studies; (2) when found, displacement was never complete and (3) diffusion of benefits occurred in 39 of the studies (Guerette and Bowers 2009).

The period has also seen useful additions to the theory underlying situational crime prevention, perhaps the most important of which was Wortley's $(1997,2001)$ argument that situations are not just passive providers of opportunities for crime, but they can also precipitate crime $^{j}$. His careful enumeration of the many ways that this can occur led to an expansion of the frequently cited classification of situational prevention techniques which, thanks to his work, now number 25 (Cornish and Clarke 2003). Felson's concept of guardianship has stimulated considerable research effort, notably in terms of Eck's (2003) "double crime triangle", the inspiration for the Center for Problem-oriented Policing's logo. ${ }^{\text {k Cornish's }}$ (1994) introduction of the concept of crime scripts, that assists in laying out the various stages of a crime (from planning, commission and escape, and through even later stages of covering tracks and disposing of stolen goods) has stimulated a considerable volume of work, particularly on complex crimes such as internet child pornography (Wortley and Smallbone 2006), suicide bombings (Clarke and Newman 2006), and organized crimes of various kinds (Tremblay et al. 2001; Bullock et al. 2010; Chiu et al. 2011). This work has shown that situational crime prevention is applicable not just to "opportunistic" street crimes, but potentially to every form of crime, however complex, and however determined the offenders. 
This empirical and theoretical progress has not gone unremarked outside the small circle of environmental criminologists directly involved in this work. Garland (2001) argued in a widely read book on criminology and public policy that opportunity theory (or what he called the "criminologies of everyday life") had been more influential in recent decades than any other criminological approach, though this was disputed by Young (2003), the originator of the term "administrative criminology", in an unusually long review essay (Young 2003). Judged by various government White Papers and other reports, the latest of which is The Government's Approach to Crime Prevention (Home Affairs Committee, 2010), situational crime prevention has directly contributed to crime policy thinking in the United Kingdom, if not also in some other European countries. To date, however, situational prevention has made relatively little impression on American criminology, perhaps because American criminology is focused even more strongly on dispositional theory than the criminology of other countries. But even this might change: Cullen, a former president of the American Society of Criminology and redoubtable dispositional theorist, made the following remarks on recently being nominated for the Society's premier award: " "If you have not heard of ECCA, it means that you likely know nothing about crime - but you should." Cullen (2011): 314.

ECCA's growing influence is one example of the growth in the institutional strength of environmental criminology. ECCA members have promoted teaching of environmental criminology in their universities, including Huddersfield and Loughborough in the U.K, Twente University and the NSCR in Holland, Griffiths University in Queensland, Simon Fraser University in Canada, and in the United States, Rutgers, University of Cincinnati, Temple University, and, finally, Texas State at San Marcos, where Felson has recently joined Rossmo and other environmental criminologists.

Another important example of growing institutional strength is the rise to prominence of the Popcenter, the web-site (www.popcenter.org) of the Center for Problem-oriented Policing which is funded by the U.S. Department of Justice. In the ten years of its existence Popcenter has become an indispensable resource for those involved in problem-oriented policing and situational crime prevention. More than 80,000 files per month are downloaded from the website, equally by students and police officers.

The jewel in the crown of the emerging empire in crime science, for me, however, is the Jill Dando Institute of Crime Science, founded at University College London, through the combined efforts of Nick Ross (the former presenter of Crimewatch, the BBC television program) and Ken Pease. From its modest beginnings some ten years ago when it consisted of little more than its director, Gloria Laycock, a trust fund, a secretary and box of books it has grown to a formidable Institute within UCL's faculty of engineering, with more than thirty staff members and Ph.D. students.

\section{What has been achieved by the work on opportunity and crime - that is to say, "So what"?}

As a result of the developments listed above, it is possible to make much bolder claims for the role of opportunity in crime, as follows:

1. Criminally-disposed people will commit more crimes if they encounter more criminal opportunities.

2. Regularly encountering such opportunities can lead these people to seek even more opportunities.

3. At the point of deciding to commit a crime, opportunity plays a more important role that dispositions.

4. The existence of easy opportunities for crime enables some people to lead a life of crime.

5. People without pre-existing dispositions can be drawn into criminal behaviour by a proliferation of criminal opportunities, and generally law-abiding people can be drawn into committing specific forms of crime if they regularly encounter easy opportunities for these crimes, especially in their occupations.

6. The more opportunities for crime that exist, the more crime there will be.

7. Reducing opportunities for specific forms of crime will reduce the overall amount of crime.

While consistent with available evidence, it must be acknowledged that the evidence supporting these claims needs to be strengthened. However, the final and perhaps most important claim is supported by Van Dijk et al's. (2012) edited volume whose contributors collectively argue that improved security is the best explanation for the recent declines in crime in most Western countries. If their thesis holds it will have a profound influence on criminological theory and crime policy. For the remaining claims, doubters might consider the following:

"Suppose all situational controls were abandoned: no locks, no custom controls, cash left for parking in an open pot for occasional collection, no library checkouts, no baggage screening at airports, no ticket checks at train stations, no traffic lights, etc. Would there be no change in the volume of crime and disorder? (Tilley and Laycock, 2002:31).

\section{Conclusions}

It is difficult to sum up the contributions made to criminology and crime policy by the work on opportunity- and 
particularly difficult to separate this work from other important strands of environmental criminology. It can be argued, however, that the work has contributed to four major achievements:

1. It has supported the development of situational crime prevention, a highly effective means of crime control.

2. It has helped make credible the claim that the cumulative effect of situational prevention, whether or not implemented under that label, has brought about widespread drops in crime in Western countries.

3. It has helped to clarify that most criminological theories are theories of criminality not theories of crime - in other words, criminological theorizing has been preoccupied with the question of why certain individuals or groups become involved in crime and not the question of why crime occurs. This latter question cannot be answered simply by explaining why some people are more likely to be delinquent or criminal; it must also be explained how situational factors facilitate or encourage the actual commission of criminal acts.

4. It has supported the development of an alternative set of crime (or opportunity) theories that will enable the growth of crime science.

\section{Final word}

My professional quest to persuade skeptical criminological colleagues of the commonsense truth of an everyday saying about crime - opportunity makes the thief - might seem quixotic, but I believe this work will free crime scientists (who have taken on the mantle of opportunity-reduction) from the problem of cause and enable them to address other challenges facing them. These will include developing more comprehensive crime opportunity theories and more detailed models of crime. Indeed, it is entirely to be expected that crime scientists, who now have an established place in academia, will increasingly engage in these kinds of theoretical endeavors that serve academia's interests. In concluding, therefore, I cannot help but express the wish that abstract theorizing and model building will not divert crime scientists too far away from the pragmatic, problem solving work of reducing crime, piece by piece. While this might have less academic caché, in my view it should always be the real goal of crime science.

\section{Endnotes}

a. This paper reviews the work of environmental criminologists, but only to the extent needed to answer these questions. Much of their important and interesting work is therefore not covered. b. It is not that criminologists were unaware of this principle, but they have regarded it as a truism or a "platitude" (Cohen, 1985: 223) that does not assist in explaining who becomes delinquent or criminal.

c. Thanks to Derek Cornish for recently drawing this to my attention.

d. We did find support from a highly unexpected source, The New Criminology (Taylor et al. 1973: 61), the bible of deviancy sociology: "Men rob banks because they believe they may enrich themselves, not because something biologically propels them through the door ..."

e. Pease and Laycock (2011) point out that Crime as Opportunity failed to mention some important psychological experiments - in particular Zimbardo's (Haney et al. 1973) simulated prison experiments and Milgram's (1974) studies in obedience - showing that deviant behavior is heavily influenced by situational factors. Again, these studies were rarely cited in the criminological literature and, for us, they differed importantly from our work on opportunity: the psychological experiments were investigating the effect of pressure to behave cruelly in a laboratory setting, while our studies were concerned with the extent to which opportunity passively provides the occasion for committing any kind of crime in the real world.

f. Barbara Wootton was not just an outstanding social scientist but she was also remarkably independent in her views. This is revealed by her musings as a magistrate when faced during World War II with a decision to commit an "exceptionally beautiful" 16-year old girl to custodial care for accepting money for sleeping with American airmen: "I just could not persuade myself that a night or two a week with a personable American was so immensely more degrading than 40 hours or more unskilled and uninteresting work in a factory" (Wootton (1978):158).

g. Numerous more comprehensive studies have documented the relationship between homicide and gun availability (e.g. Cook and Ludwig 2002).

h. Strictly-speaking the findings about displacement showed only that situational crime prevention is effective, not that opportunity is a cause of crime. But they did help to counter the argument that opportunity and situational factors determine only the time and place of crime, not whether or not it occurs. This was because the results showed that reducing opportunities through situational prevention measures did reduce the amount of crime that occurred.

i. One of the most important of these was Farrell and Pease (1993) that set out the evidence for repeat victimization. Reducing repeat victimisation was subsequently established by the Home Office as an official measure of police performance.

j. Nick Ross has continually reminded me that temptation, not merely opportunity, plays a substantial role in crime. 
k. The double crime triangle was created to help police analyze crime problems and identify possible solutions. The three sides of the inner triangle are labeled offender, place and target/victim, while the three sides of the outer triangle are labeled with three controlling agents: "handlers" control offenders, "place managers" protect places, and "guardians protect target/victims.

1. It is enjoyable irony for me that this is called the "Sutherland Award". Cullen's endorsement of ECCA might not be entirely unrelated to the fact that he and John Eck are colleagues at the University of Cincinnati. They are also friends and live across the street from each other. It was ever thus that personal contacts have channeled the flow of knowledge!

\section{Competing interests}

The author declares that he has no competing interests.

\section{Acknowledgements}

This is an edited version of my talk at the book launch for The Reasoning Criminologist (Tilley and Farrell 2011) arranged by the Jill Dando Institute of Crime science, UCL, on June 15, 2012. I want to express my thanks to Graham Farrell and Nick Tilley for conceiving of the book and bringing it to publication, to my friends and colleagues for their valuable contributions to the book, and to Richard Wortley for arranging and, because I fell ill, rearranging the launch of the book. I am deeply grateful to them all. I hope this paper will not reinforce an unfortunate impression conveyed by the book - that I did all this work on my own. Far from it. Whatever the topic, I have always worked closely with one or more colleagues. These were not always the same people - in fact, I think of myself as a serial collaborator but whoever was involved, collaboration greatly strengthened the work and made it much more enjoyable. Finally, I should like to thank the four anonymous reviewers for their helpful suggestions.

Received: 24 July 2012 Accepted: 26 November 2012

Published: 17 December 2012

\section{References}

Armitage R, Smithson H (2007) Alley-gating revisited: The sustainability of residents' satisfaction. Internet J Criminol :1-38

Beeson M (1976) Review of "Crime as Opportunity". Prison Serv J 24(October):20 Bowers K, Johnson S, Hirschfield A (2004) Closing off opportunities for crime: An evaluation of alley-gating. Eur J Crim Policy Res 10:285-308

Brantingham PJ, Brantingham PL (eds) (1981) Environmental Criminology. Sage, Beverly Hills

Bullock K, Clarke RV, Tilley N (eds) (2010) Situational Prevention of Organized Crimes. Willan Publishing, Devon, England

Chiu Y-N, Leclerc B, Townsley M (2011) Crime script analysis of drug manufacturing in clandestine laboratories: Implications for strategic intervention. Br J Criminol 51:355-374

Clarke RV (In press) Affect and the Reasoning Criminal: Past and future. In: van Gelder JL, Elffers H, Reynald D, Nagin D (eds) Affect and Cognition in Criminal Decision Making. Routledge. London Routledge, London

Clarke RV, Cornish DB (1985) Modeling offenders' decisions: A framework for research and policy. In: Tonry M, Morris N (eds) Crime and Justice, vol 6. University of Chicago Press, Chicago

Clarke RV, Kemper R, Wyckoff L (2001) Controlling cell phone fraud in the U.S. Lessons for the U.K. 'Foresight' prevention initiative. Secur J 14:7-22

Clarke RV, Martin DN (1971) Absconding from Approved Schools. Home Office Research Study 12. HMSO, London

Clarke RV, Mayhew P (1988) The British gas suicide story and its criminological implications. In: Tonry M, Morris N (eds) Crime and Justice: An Annual Review of Research, vol 10. University of Chicago Press, Chicago, IL

Clarke RV, Mayhew P (1998) Preventing crime in parking lots: What we know and what we need to know. In: Felson M, Peiser R (eds) Reducing Crime through Real Estate Development and Management. Urban Land Institute, Washington D.C
Clarke RV, Newman GR (2006) Outsmarting the Terrorists. Preager Security International, Westport, CT

Clarke RV, Weisburd D (1994) Diffusion of crime control benefits: Observations on the reverse of displacement. In: Clarke RV (ed) Crime Prevention Studies, vol 2. Criminal Justice Press, Monsey, NY

Cohen AK (1985) The assumption that crime is a product of environments: Sociological approaches. In: Meier RF (ed) Theoretical Methods in Criminology. Sage, Beverly Hills, CA, pp 223-243

Cohen AK, Lindesmith A, Schuessler K (1956) The Sutherland Papers. Indiana University Press, Bloomington

Cohen LE, Felson M (1979) Social change and crime rate trends: A routine activity approach. Am Sociol Rev 44:588-608

Cook PJ, Ludwig J (2002) Gun Violence: The Real Costs. Oxford University Press, Oxford

Cornish DB (1994) The procedural analysis of offending, and its relevance for situational prevention. In: Clarke RV (ed) Crime Prevention Studies, Vol 3. Criminal Justice Press, Monsey, NY

Cornish DB, Clarke RV (eds) (1986) The Reasoning Criminal: Rational Choice Perspectives on Offending. Springer-Verlag, New York

Cornish DB, Clarke RV (2003) Opportunities, Precipitators and Criminal Decisions. Crime Prevention Studies, 16th edn. Criminal Justice Press, Monsey, NY

Cullen FT (2011) Beyond adolescence-limited criminology: choosing our future. The American Society of Criminology 2010 Sutherland Address. Criminology 49(2):287-330

Eck JE (1993) The threat of crime displacement. Crim Justice Abstr 25:527-546

Eck J (2003) Police problems: The complexity of problem theory, research and evaluation. In: Knutsson J (ed) Problem-Oriented Policing: From Innovation to Mainstream. Crime Prevention Studies, 15th edn. Criminal Justice Press, Monsey, New York

Ekblom P (1994) Proximal circumstances: A mechanism-based classification of crime prevention. In: Clarke RV (ed) Crime Prevention Studies, 2nd edn., pp 185-232

Farrell G, Pease K (1993) Once Bitten, Twice Bitten: Repeat Victimisation and its Implications for Crime Prevention. Crime Prevention Unit Series, Paper 46. Police Research Group. Home Office, London

Felson M (1986) Linking criminal choices, routine activities, informal contro and criminal outcomes. In: Cornish DB, Clarke RV (eds) The Reasoning Criminal: Rational Choice Perspectives on Offending. Springer-Verlag, New York

Felson M (1994) Crime and Everyday Life. Pine Forge Press, Thousand Oaks, CA

Felson M, Clarke RV (1998) Opportunity Makes the Thief: Practical Theory for Crime Prevention. Police Research Series, Paper 98. Home Office, London

Garland D (2001) The Culture of Control: Crime and Social Order in Contemporary Society. University of Chicago Press, Chicago

Guerette RT, Bowers K (2009) Assessing the extent of crime displacement and diffusion of benefits: A review of situational crime prevention evaluations. Criminology 47:1331-1368

Haney C, Banks C, Zimbardo P (1973) Interpersonal dynamics in a simulated prison. Int J Crim Penology 1:69-97

Hartshorne H, May HA (1928) Studies in Deceit. Macmillan, New York

Hesseling RBP (1994) Displacement: A review of the empirical literature, Crime Prevention Studies, vol 3. Criminal Justice Press, Monsey, NY

Home Affairs Committee (2010) The Government's Approach to Crime Prevention. House of Commons HC 242-1. The Stationery Office Limited, London

Hough M, Mayhew P (2011) Situational crime prevention: The Home Office origins. In: Tilley N, Farrell G (eds) The Reasoning Criminologist: Essays in Honour of Ronald V. Clarke. Routledge, London

Jeffery CR (1971) Crime Prevention through Environmental Design. Sage, Beverly Hills

Mayhew P, Clarke RV, Elliott D (1989) Motorcycle theft, helmet legislation and displacement. Howard J Crim Justice 28:1-8

Mayhew PM, Clarke RVG, Sturman A, Hough JM (1976) Crime as Opportunity. Home Office Research Study, No 34. H.M.S.O, London

Merton RK (1995) Opportunity structure: The emergence, diffusion, and differentiation of a sociological concept, 1930s-1950. In: The Legacy of Anomie Theory, Advances in Criminological Theory, 6th edn. Transaction Publishers, New Brunswick, NJ, pp 3-78

Milgram S (1974) Obedience to Authority: An Experimental View. Harper \& Row, New York 
Mischel W (1968) Personality and Assessment. Wiley, New York

Newman O (1972) Defensible Space: Crime Prevention through Urban Design. MacMillan, New York

Pease K (1991) The Kirkholt Project: Preventing burglary on a British public housing estate. Secur J 2:73-77

Pease K, Laycock G (2011) Ron and the Schiphol Fly. In: Nick T, Graham F (eds) The Reasoning Criminologist: Essays in Honour of Ronald V. Clarke. Routledge, London

Sutherland EH (1947) Principles of Criminology, 3rd edn. JB Lippincott, New York Sutherland EH (1956) The Swansong of Differential Association. In: Cohen AK, Lindesmith A, Schuessler K (eds) The Sutherland Papers. Indiana University Press, Bloomington

Taylor I, Walton P, Young J (1973) The New Criminology. Routledge \& Kegan Paul, London

Tilley N, Laycock G (2002) Working Out What to Do: Evidence-Based Crime Reduction. Crime Reduction Research Series Paper 11. Home Office, London

Tilley N, Farrell G (eds) (2011) The Reasoning Criminologist: Essays in Honour of Ronald V. Clarke. Routledge, London

Tremblay P, Talon B, Hurley D (2001) Body switching and related adaptations in the resale of stolen vehicles: Script elaborations and aggregate crime learning curves. Br J Criminol 41:561-579

Van Dijk J, Tseloni A, Farrell G (eds) (2012) The International Crime Drop. Palgrave Macmillan, London

Wilson JQ (1975) Thinking about Crime. Basic Books, New York

Wootton B (1950) Testament for Social Science. Allen and Unwin, London

Wootton B (1978) Crime and Penal Policy: Reflections on Fifty Years' Experience. George Allen and Unwin, London

Wortley R (1997) Reconsidering the role of opportunity in situational crime prevention. In: Newman G et al (eds) Rational Choice and Situational Crime Prevention. Aldershot, Dartmouth

Wortley R (2001) A classification of techniques for controlling situational precipitators of crime. Secur J 14:63-82

Wortley R, Smallbone S (2006) Child pornography on the Internet. ProblemOriented Guides for Police Series. U.S. Department of Justice, Washington DC Young J (2003) Searching for a new criminology of everyday life. Review article of Garland, D., The Culture of Control. British J Crim 43(1):228-242

doi:10.1186/2193-7680-1-3

Cite this article as: Clarke: Opportunity makes the thief. Really? And so what?. Crime Science 2012 1:3.

\section{Submit your manuscript to a SpringerOpen ${ }^{\circ}$ journal and benefit from:}

- Convenient online submission

- Rigorous peer review

- Immediate publication on acceptance

- Open access: articles freely available online

- High visibility within the field

- Retaining the copyright to your article

Submit your next manuscript at $\gg$ springeropen.com 